\title{
OKOLICZNOŚCI FUNDACJI KLASZTORU KANONIKÓW REGULARNYCH W KRAŚNIKU
}

\begin{abstract}
Wstęp
Klasztor Kanoników Regularnych w Kraśniku stanowi dzieło jednego z najpotężniejszych i najbardziej wpływowych rodzin średniowiecznej Polski - Tęczyńskich herbu Topór. Zachowane oryginalne dokumenty fundacyjne wystawione przez Jana Rabsztyńskiego z Rabsztyna i Tęczyna, późniejszego kasztelana wiślickiego i starosty sandomierskiego, biskupa krakowskiego Jana z Brzezia oraz dokument zatwierdzający fundację wystawiony przez komisarza papieskiego Jana, opata cystersów z Koprzywnicy, przekonują nas o tym ponad wszelką wątpliwość.

Okoliczności, jakie wpłynęły na powstanie klasztoru kraśnickiego, naświetlano w literarurze przedmiotu zwykle z punktu widzenia przesłanek zawartych w dokumencie fundacyjnym Jana Rabsztyńskiego. Podsumowanie tych ustaleń znajdujemy we wstępnym rozdziale pracy Ewy Zielińskiej poświęconej kulturze kanoników regularnych z Kraśnika ${ }^{1}$. W niniejszym artykule, nie powielając wiadomości o faktach już znanych, zwrócimy uwagę na okoliczności dalsze, choć nie mniej ważne, wynikające z losów rodu Tęczyńskich, które tworzyły tło fundacji kraśnickiej i w jakimś stopniu, z pewną konsekwencją, do niej prowadziły. Postaramy się więc odpowiedzieć na pytania o idee, czynniki, jakie skłoniły Tęczyńskich do przemianowania kościoła parafialnego w Kraśniku w kościół zakonny i ostatecznie wyboru właśnie kanoników regularnych. Wreszcie przywołamy nieznay w zasadzie kontekst związków rodzinnych pomiędzy Tęczyńskimi i kanonikami regularnymi.

Do naszych rozważań znakomitego materiału faktograficznego dostarczył Janusz Kurtyka w swojej monografii poświęconej rodowi Toporczyków². Na pod-

* Ks. Włodzimierz Bielak - dr hab. historii Kościoła; prof. w Katedrze Historii Kościoła w Starożytności i Średniowieczu, Isnstytut Historii Kościoła i Patrologii KUL; e-mail: bielakwl@kul.pl

${ }^{1}$ E. Zielińska, Kultura intelektualna kanoników regularnych z klasztoru w Kraśniku 1469 -1563, Lublin 2002.

${ }^{2}$ J. Kurtyka, Tęczyńscy. Studium z dziejów polskiej elity możnowładczej w średniowieczu, Kraków 1997.
\end{abstract}


stawie zebranych przez niego danych będziemy starali się odkryć w losach członków rodu Tęczyńskich zalążki przyszłej fundacji w Kraśniku.

\section{Okoliczności determinujące fundację klasztorną w Kraśniku}

W dziejach rodu herbu Topór można wyróżnić pewne momenty przełomowe wyznaczające wzloty i upadki w karierze politycznej jego członków oraz znaczeniu społecznym całej familii. Dotyczy to również szczególnie nas interesującej rodziny Tęczyńskich, mającej siedlisko w Morawicy, a z biegiem lat pomnażającej swe posiadłości w Małopolsce i dochodzącej do najwyższych urzędów w państwie. Andrzej, syn protoplasty tej gałęzi rodowej, Nawoja z Morawicy, w czasach Kazimierza Wielkiego był wojewodą krakowskim, uczestnikiem wypraw zbrojnych króla na Ruś. Jemu przypisuje się budowę zamku Tęczyn, od którego Tęczyńscy wzięli swoje miano i zaznaczyli odrębność w rodzie Toporczyków. Na świetny rozwój kariery i honor rodziny cień rzucił postępek syna wojewody krakowskiego, Nawoja. Pod koniec życia Kazimierza Wielkiego doszło do interwencji polskiej w Mołdawii. Jej uczestnikiem był wspomniany Nawój. W czasie walk na Pokuciu rycerstwo polskie zostało wciągnięte w zasadzkę. Wtedy Nawój porzucił niesioną przez siebie chorągiew $\mathrm{z}$ herbem Topór i uciekł z pola walki. To okryło hańbą jego i całą rodzinę. Dla winowajcy ten incydent miał konsekwencje jeszcze poważniejsze - zamknął mu drogę do kariery w strukturach władzy świeckiej. Powróciwszy w rodzinne strony i zaznawszy smaku dezaprobaty ze strony rodowców wyjechał do Italii, gdzie ukończył studia prawnicze. Gdy nieco ucichły już echa skandalu, w 1373 roku wrócił do Polski i rozpoczął karierę w stanie duchownym. Najpierw objął probostwo w rodzinnej Morawicy. Pochodzenie ze znakomitego i skoligaconego rodu, pozwoliło mu wkrótce zyskać urzędy bardziej znaczące. Wkrótce został kanonikiem i dziekanem krakowskim.

Zajście na Pokuciu pozostawiło też piętno na rodzinie Toporów, przyczyniając się do pomniejszenia jej znaczenia w kręgach ówczesnych elit. Wyrazem niełaski w jaką popadli Teczyńscy było odwołanie przez Kazimierza Wielkiego Ottona z Pilicy z urzędu starosty ruskiego. Na małe znaczenie polityczne Tęczyńskich w tym okresie wpłynęła rówież reprezentowana przez nich opcja polityczna, przeciwna proluksemburskiej polityce Ludwika Węgierskiego. Powrót do łask zajął Tęczyńskim całą dekadę. Dogodne warunki pojawiły się w czasie odwetowej, za najazd Litwinów, wyprawy do Bełza. Na tę wojnę Toporczycy wystawili wyjątkowo okazały, bo składający się z siedmiu chorągwi, zastęp rycerstwa. Kampania była udana, a udział Tęczyńskich znaczny. Skutkiem tych wydarzeń w 1379 roku brat skompromitowanego Nawoja, Jan, otrzymał kasztelanię wiślicką, a sam Nawój kanonię krakowską. Rok 1379 jest więc przełomowy w dziejach rodu Tęczyńskich. Powrót do ścisłego grona establishmentu możnowładczego bracia Nawój i Jan zaakcentowali fundacją ołtarza pod wezwaniem św. Andrzeja w katedrze krakowskiej. Główną rolę w akcie tej fundacji odegrał Nawój - sprawca upokorzenia Tęczyńskich. Po wzniesieniu zamku Tęczyn, jest to druga fundacja mani- 
festująca potęgę Tęczyńskich i ich odrębność w rodzie Toporów. Ponadto Nawój ufundował, jako osobiste wotum, dzwon zwany nawojowym lub półzygmuntem ${ }^{3}$.

W okresie starań o obsadzenie na tronie polskim Jadwigi Andegaweńskiej, w czasie rządów jej i Władysława Jagiełły, Jan Tęczyński († 20 X 1405) doszedł do najwyższych godności i urzędów państwowych: był namiestnikiem Królestwa i kasztelanem krakowskim. Zapewniły mu to bliskie związki z dworem królowej i reprezentowanie tej samej co ona linii politycznej przy tworzeniu unii polsko-litewskiej. Wysoką pozycję Tęczyńskich udało się utrzymać synowi Jana, Andrzejowi, który piastując urząd kasztelana wojnickiego, należał do najbliższego otoczenia Władysława Jagiełły. Gdy Andrzej zmarł w 1411 lub 1412 roku, rola przywódcza Tęczyńskich przypadła jego bratu Nawojowi przeznaczonemu przez ojca do kariery dychownej. Widocznie na tym imieniu ciążyło jakieś fatum, bowiem stał się on sprawcą kolejnych kłopotów Tęczyńskich. Porzucił karierę duchowną, ale do polityki zdecydowanie nie nadawał się. Przyniósł niesławę rodzinie przede wszystkim rozrzutnością, zaciąganiem coraz to nowych długów, podejrzanymi transakcjami finansowymi. Tracił w ten sposób zaufanie i narażał na szwank interesy rodziny. Wreszcie wziął za żonę córkę Męciny z Gowarczowa, kobietę dość niskiego pochodzenia. Ten mezalians doprowadził do zepchnięcia Nawoja na odległe miejsce w strukturach elit politycznych lub był wynikiem drastycznego spadku poważania, co czyniło z Nawoja nieatrakcyją partię w rachubach koligacyjnych. Oczywiście cierpiała na tym cała rodzina ${ }^{4}$.

Odzyskanie prestiżu stało się zadaniem dwóch synów kasztelana wojnickiego Andrzeja: Jana i Andrzeja. Ta sztuka się udała. Starszy z braci, Jan, dostał się do grona oligarchów krakowskich mających realny wpływ na system rządów w Królestwie. Obok biskupa Zbigniewa Oleśnickiego należał do pierwszoplanowych postaci w tym środowisku. W karierze politycznej doszedł do najwyższego urzędu świeckiego w państwie - kaszelanii krakowskiej. Jego niekwestionowana wysoka pozycja społeczna sprawiła, że stał się nestorem Tęczyńskich. Powrót do łask i urzędów zapewne zaspokajały ambicje Jana i całej rodziny. Wewnętrzna polityka Kazimierza Jagiellończyka doprowadziła jednak ostatecznie w 1461 roku do upadku znaczenia grupy oligarchicznej. Wtedy Jan, kasztelan krakowski, poświęcił swe siły umacnianiu ekonomicznemu rodziny i zachowaniu jej prestiżu społecznego ${ }^{5}$.

Drugi z braci, Andrzej, ojciec fundatora klasztoru w Kraśniku, był bardziej wojownikiem niż politykiem. Uczestniczył $w$ wydarzeniach związanych z konfederacją Spytka z Melsztyna, najpierw stając po jej stronie, a później przeciw. Popierał osadzenie na tronie węgierskim Władysława III Jagiellończyka i wspierał go na czele własnego oddziału rycerzy, który poprowadził do Budy. Jednak dopiero w czasie wojny pruskiej w połowie XV wieku zyskał należną sławę. Przechodzenie z obozu oligarchów, kierowanego przez Zbigniewa Oleśnickiego do grupy juniorów związanych z Zofią Holsztańską i następnie zbliżenie się do oligarchów u schyłku ich wpływów spowodowało, że ominęły go wysokie urzędy państwowe ${ }^{6}$. Jest to fakt

\footnotetext{
${ }^{3}$ Tamże, s. 181-191.

${ }^{4}$ Tamże, s. 282 nn.

${ }^{5}$ Tamże, s. 295-300, 367-382.

${ }^{6}$ Tamże, s. $465 \mathrm{nn}$.
} 
istotny, który być może zaważył na potrzebie szukania innych sposobów na zaznaczenie swej pozycji społecznej, na czym też skorzystał kościół w Kraśniku.

W 1438 roku dokonał się akt podziału dóbr między braćmi Janem i Andrzejem Tęczyńskimi. Janowi przypadły w udziale dobra należące do jego ojca, Andrzeja kasztelana wojnickiego, z zamkiem Tęczyn. Andrzej dostał dobra wniesione do rodziny przez matkę, Annę z Goraja, córkę Dymitra z Goraja, a wśród nich Kraśnik. Patronat ołtarza św. Andrzeja w katedrze krakowskiej pozostał wspólną sprawą obu braci i znakiem jedności rodziny. Majątek Andrzeja powiększył się po zawarciu małżeństwa z Jadwigą z Książa, córką Jana Melsztyńskiego. Warto już w tym miejscu zwrócić uwagę, że konkurentem do jej ręki był Zbigniew, syn Jana Głowacza z Oleśnicy, bratanek biskupa krakowskiego Zbigniewa Oleśnickiego. Jadwiga wniosła mu w posagu m.in. Książ i zamek Rabsztyn. Te dwa wydarzenia, podział dóbr należących do Tęczyńskich i ożenek z Jadwigą Ksiąską, zapoczątkowały tworzenie się nowej linii rodzinnej - Rabsztyńskich. Otrzymawszy własny dział, Andrzej zyskał samodzielność, ale żeniąc się z Jadwigą Melsztyńską wiązał się ze znakomitym rodem i nie mając takiej pozycji, jak jego brat, mógł łatwo zostać przezeń zdominowany. Na razie nad wszystkim czuwał wpływowy brat Jan, który miał plan przyciągnięcia do obozu oligarchów potomków opozycyjnego Spytka z Melsztyna oraz samego Andrzeja, lecz w razie jego śmierci sprawy mogły wziąć inny obrót. Jako protoplasta nowej gałęzi genealogicznej - Tęczyńskich z Rabsztyna, Andrzej musiał zaznaczyć jakoś swoją pozycję. Aż tak zdeterminowany nie był Jan, jako dziedzic rodowych dóbr i kasztelan krakowski, lecz i on kazał przetopić i odlać na nowo dzwon Nawojowy oraz ozdobić go herbem Topór; dziś zwany jest Tęczyńskim. Podkreślenie swego znaczenia było dla Andrzeja sprawą ważną, po pierwsze w obliczu utraty wpływów politycznych przez obóz oligarchiczny, w tym współdzielił los brata, po drugie wobec Melsztyńskich, jeśli miał być dla nich równoprawnym partnerem bez kurateli kasztelana Jana. Książ był znanym i ważnym ośrodkiem, a tamtejszy klasztor augustianów pełnił rolę mauzoleum Melsztyńskich; podobnie kolegiata Wszystkich Swiętych w Krakowie była rodową świątynią Melsztyńskich i Tarnowskich. Andrzej Tęczyński potrzebował podobnego jak Tęczyn i Książ siedliska, ale będącego jego własnym dziełem. Uwagę zwrócił ku Kraśnikowi. Własną pozycję społeczną należało podkreślić znaczną i wyrazistą fundacją. Grunt pod nią przygotowywali Tęczyńscy już od jakiegoś czasu. Wstępem do niej było obsadzenie probostwa w Kraśniku rodowcem, Andrzejem Kalińskim herbu Topór. Pleban kraśnicki o tym imieniu występuje już w 1435 roku. Wybudował on murowane prezbiterium i zakrystię przy kościele parafialnym. Ostatecznie świątynia parafialna miała być przekształcona w zakonną. Fundacja klasztoru najbardziej odpowiadałaby aspiracjom i możliwościom Andrzeja Rabsztyńskiego. Wpisałaby się też ona w rodową tradycję zaznaczania swej pozycji fundacjami kościelnymi. Inne fundacje były albo mało atrakcyjne, np. kolejnego ołtarza lub rozbudowa istniejącej już parafii, albo zbyt trudne lub wręcz niemożliwe do realizacj, np. kolegiaty, dla której prowincjonalny Kraśnik w tamtym czasie stanowił zbyt niskie progi ${ }^{7}$.

${ }^{7}$ Tamże, s. 413-415, 467-471, 494, 501 
Z zamiarem założenia konwentu nosił się już Andrzej Tęczyński. Zaświadczył o tym jego syn, Jan Rabsztyński, w dokumencie fundacyjnym klasztoru Kanoników Regularnych Laterańskich: „cuius animus dum adhuc in humanis agebat fervencius et intimius ad hoc estuabat et quottidie hoc perficere cogitabat nec non successorum meorum et heredum preccaminum remedio"s. Nie wiemy o jakim zakonie myślał Andrzej, ale zapewne nie o augustianach ${ }^{9}$. Ci zbyt mocno kojarzyli się z Melsztyńskimi, a przecież nie o kontynuację ich idei mu chodziło, lecz o własną inicjatywę.

Fundacja klasztoru w Kraśniku była więc częścią tradycji gruntującej pozycję społeczną Tęczyńskich oraz odrębność w gałęziach rodowych: budowa zamku Tęczyn i fundacja ołtarza św. Andrzeja w katedrze krakowskiej niewątpliwie dodawały miru i były oznaką potęgi kasztelana Jana, pradziadka fundatora klasztoru w Kraśniku, oraz jego brata Nawoja (pomimo jego wcześniejszego upokorzenia). Klasztor w Kraśniku pieczętował odrębność Rabsztyńskich. Nawet jeśli za czasów fundatora konwentu i jego ojca Kraśnik nie dorównywał Książowi, to mógł pretendować do podobnej rangi. Oddanie kościoła parafialnego w Kraśniku, fundowanego, oczywiście jeśli tak było w istocie, przez Gorajskich, zakonowi, pokazywało wyższość Tęczyńskich nad Gorajskimi, zaś odejście od tradycji Jadwigi Ksiąskiej, przywiązanej do augustianów, stawiało Rabsztyńskich na podobnej pozycji wobec Melsztyńskich.

W ten sposób losy Tęczyńskich w XIV i XV wieku prowadziły z jakąś konsekwencją do powstania w Kraśniku klasztoru.

\section{Okoliczności implikujące sprowadzenie do Kraśnika kanoników regularnych}

Dochodzimy do pytania o przyczyny wyboru Kanoników Regularnych Laterańskich na gospodarzy placówki duszpasterskiej w Kraśniku. Najbardziej banalna odpowiedź byłaby taka, że kanonicy regularni byli w owym czasie najprężniejszem zakonem, któremu udało się oprzeć kryzysowi, jaki dotykał w XV wieku inne zakony. Oczywiście nie jest to okoliczność bez znaczenia i należy ją brać pod uwagę, ale wobec inych przesłanek, najprawdopodobniej nie najważniejsza. Znalazły się wszakże inne bodźce kierujące uwagę Tęczyńskich ku kanonikom regularnym. Jednym $\mathrm{z}$ nich były związki Tęczyńskich z klerem diecezjalnym; tylko pozornie przeczyłyby one zwrotowi ku zakonom i kazałyby szukać realizacji zamierzeń Tęczyńskich w strukturach diecezji. Zażyłość z kolegium wikariuszy katedralnych sięga XIV wieku i obejmuje przynajmniej trzy pokolenia

\footnotetext{
${ }^{8}$ Archiwum Narodowe w Krakowie, Perg. 887 (edycja dokumentu: W. Bielak, Dokument fundacyjny klasztoru Kanoników Regularnych Laterańskich w Kraśniku, „Archiwa Biblioteki i Muzea Kościelne", 107 (2017) s. 26-30).

${ }^{9}$ J. Kurtyka sugerował, że zamiłowanie do augustianów wziął Andrzej właśnie od Melsztyńskich. Uważamy jednak tę tezę za nieprawdziwą. Poza tym nastąpiła zapewne pomyłka polegająca na utożsamianiu augustianów i kanoników regularnych. Kwestię właściwego rozróżnienia tych dwóch zakonów rozstrzygnął K. Łatak, Augustianie czy kanonicy regularni. Glos w sprawie poprawnej denominacji, w: Przemijanie i trwanie. Kanonicy regularni w dawnej $i$ wspótczesnej Polsce, Kraków [2008], s. 39-44.
} 
Tęczyńskich. Bracia Nawój i Jan Tęczyńscy są określani w kalendarzu katerdy krakowskiej, jako dobrodzieje wikariuszy. Zresztą nie tylko oni mają tam swe noty nekrologiczne. W XIV wieku wpisy dotyczące Tęczyńskich są najliczniejsze spośród wszystkich innych znacznych rodzin z tego okresu. Ten m.in. fakt świadczy o sympatiach do tej właśnie grupy duchowieństwa. Sympatie miały swe konkretne skutki - rodzinny ołtarz św. Andrzeja dawał wikariuszom utrzymanie ${ }^{10}$. Podobne relacje łączyły Tęczyńskich z kapitułami. Wśród kanoników kolegiaty św. Idziego, pozostającej pod ich patronatem, przeważali przedstawiciele tego rodu ${ }^{11}$. Tęczyńscy byli również kanonikami innych kapituł. Spośród potomków Nawoja z Morawicy było co najmniej 9 kanoników, w tym niektórzy zasiadali jednocześnie w dwóch lub więcej kapitułach. Kanonikiem krakowskim był również ojciec fundatora klasztoru kraśnickiego, Andrzej. Specyfika kanoników regularnych, stawiająca ich bliżej duchowieństwa diecezjalnego niż mniszego, oraz związki Tęczyńskich z klerem diecezjalnym i kanonikami kapitulnymi, mogła kierować uwagę Andrzeja i dwóch Janów (jego brata i syna) właśnie w stronę tego zakonu, dając mu w ich oczach przewagę nad innymi zgromadzeniami.

Z kanonikami regularnymi Tęczyńscy zetknęli się bezpośrednio w okresie fundacji klasztoru Bożego Ciała w Krakowie. Pradziadek fundatora klasztoru w Kraśniku, Jan z Tęczyna, kasztelan krakowski († 20 X 1405), był wykonawcą testamentu królowej Jadwigi, której przypisuje się główny impuls sprowadzenia tegoż zakony z Kłodzka do Krakowa. Jego podpis widnieje wśród świadków na dokumencie fundacyjnym klasztoru Bożego Ciała w Krakowie wystawionym przez Władysława Jagiełłę 26 III 1405 roku $^{12}$.

Kolejnym impulsem do zainteresowania się kanonikami regularnymi były związki Tęczyńskich z Akademią Krakowską. Związki te zaznaczyły się od początku istnienia odnowionej Alma Mater, a nawet wyprzedzały inaugurację roku akademickiego w lipcu 1400 roku. Wspomniany wyżej Jan z Tęczyna, kasztelan krakowski, był zaangażowany nie tylko powstanie Klasztoru Bożego Ciała, lecz również w restaurację uniwersytetu, znów jako jeden $\mathrm{z}$ wykonawców testamentu królowej Jadwigi. W metryce uniwersyteckiej zapisano go wśród osób najbardziej zasłużonych dla odnowienia akademii. Zasługi położył nie tylko na polu działań prawnych, lecz również uposażenia uczelni, np. w imieniu Toporczyków oddał uniwersytetowi połowę praw patronatu kolegiaty św. Idziego oraz skłonił Niemierzę z Krzelowa, aby włączył ufundowaną przez siebie altarię Wszystkich Świętych w katedrze krakowskiej do uposażenia akademii ${ }^{13}$.

Z Uniwersytetem Krakowskim byli związani Kanonicy Regularni Laterańscy. Uważa się, że Władysław Jagiełło założył klasztor Bożego Ciała w Krakowie w związku z odnowieniem uczelni - skryptoria kanoników miały zaopatrywać kadrę i studentów w niezbędne książki. Kanonicy cieszyli się życzliwością profesorów krakowskich, spośród których wielu odnotowano w nekrologu klasztornym,

\footnotetext{
${ }^{10}$ Kurtyka, Tęczyńscy, s. 264.

${ }^{11}$ Kurtyka, Tęczyńscy, s. 415.

${ }^{12}$ K. Łatak, Kongregacja krakowska Kanoników Regularnych Laterańskich na przestrzeni dziejów, Kraków 2002, s. 22; Kurtyka, Tęczyńscy, s. $541 \mathrm{nn}$.

${ }^{13}$ Kurtyka, Tęczyńscy, s. 234 nn.
} 
jako dobrodziejów, opiekunów lub przyjaciół klasztoru. Kanonicy regularni niewątpliwie odgrywali też przodującą rolę w środowisku kulturowym Krakowa ${ }^{14}$.

Kilku Tęczyńskich było studentami Uniwersytetu Krakowskiego, w tym czterech synów kasztelana krakowskiego Jana, a więc braci stryjecznych fundatora naszego klasztoru; jeden z nich, Sędziwój z Chroborza, był nawet rektorem uczelni. Do grona studentów należał Andrzej Tęczyński, ojciec fundatora. O ich wykształcenie dbał kasztelan Jan ${ }^{15}$. Na Uniwersytecie Krakowskim krzyżowały się zatem drogi Tęczyńskich i kanoników regularnych. Było to dobre miejsce, gdzie Tęczyńscy mieli możliwość zapoznać się z kanonikami.

Później, gdy Andrzej oraz jego syn, Jan, założyciel klasztoru, szukali inspiracji dla rozwoju Kraśnika, mogli je znaleźć w środowisku krakowskim, z którym rodzina związała swe losy od dawna.

Szczególnie interesującą okolicznością są koligacje rodzinne Tęczyńskich. Najpierw naszą uwagę przykuwa zapiska w nekrologu kanoników regularnych kongregacji krakowskiej. Nekrolog, używany zapewne w klasztorze Bożego Ciała $\mathrm{w}$ Krakowie, nie zachował się $\mathrm{w}$ oryginale. Jego odpis znajduje się $\mathrm{w}$ przechowywanej w Archiwum Kurii Metropolitalnej w Wilnie (AKAV) kronice Benedykta Samotulskiego ${ }^{16}$. Zapisano tam notatkę o śmierci kanonika regularnrgo z Krakowa - Wincentego Ossolińskiego. Mamy więc do czynienia z pierwszą bezpośrednią wzmianką o członku konwentu krakowskiego będącego przedstawicielem rodu Toporczyków.

Większą wagę mają jednak związki Tęczyńskich z Oleśnickimi. W 1424 roku doszło do małżeństwa Jana Głowacza Oleśnickiego, brata biskupa krakowskiego Zbigniewa, z Anną Tęczyńską, siostrą Jana, kasztelana krakowskiego i Andrzeja, ojca fundatora klasztoru. Wśród Oleśnickich, współczesnych twórcom klasztoru kraśnickiego, pojawia się w źródłach dość tajemnicza postać, o której wiadomości są tak skąpe, że niemal ginie ona w mrokach dziejów. Był nią Jakub Oleśnicki, kanonik regularny w klasztorze Bożego Ciała w Krakowie. Tradycja klasztorna przechowała o nim pamięć upublicznioną głównie dzięki spuściźnie kronikarza krakowskich kanoników regularnych, ks. Stefana Ranatowicza, który w swojej pracy pisarskiej był inspirowany dokonaniami ks. Krzysztofa Łoniewskiego, z którego zapisków korzystał ${ }^{17}$. W drugim wydaniu żywota św. Stanisława Kazimierczyka, przygotowanym do druku właśnie przez Ranatowicza, w Przedmowie do czytelnika zapisano: „Z tego potym konwentu, jako z źródła, wyszło wiele lu-

${ }^{14}$ Łatak, Kongregacja krakowska, s. 21 nn. O związkach kanoników regularnych z Akademią Krakowską: H. D. Wojtyska, Nauka i nauczanie u kanoników regularnych, w: Dzieje teologii katolickiej, red. M. Rechowicz, t. 2, cz. 2, Lublin 1975, s. 453-507.

${ }^{15}$ Kurtyka, Tęczyńscy, s. $410 \mathrm{nn}$.

${ }^{16}$ AKAV, sygn. f. 1 ep. 5b 8, Liber Canonicorum Regularium Conventus Vilnensis in Antocollo ad ecclesiam sancti Petri sub admodum Reverendo Domino Benedicto Samotulski praeposito conscriptus Anno Domini 1668 die 10 Decembris. Część kroniki zawierającej nekrolog nosi tytuł: Memoria defunctorum Canonicorum Regularium Congregationis Cracoviensis descripta ex libro Conventus Cracoviensis qui secundum mensem et diem notatur annus autem sequitur.

${ }^{17}$ K. Latak, Ksiadz Stefan Ranatowicz CRL (1617-1694). Barokowy kronikarz i pisarz klasztorny, Kraków 2010; M. Pęgier, Konstrukcja Kroniki księdza Stefana Ranatowicza CRL (1617-1694) oraz wstęny zarys problematyki, „Saeculum Christianum”, 21 (2014) s. 128. 
dzi zacnych nie tylko urodzeniem, ale i nauką, i świątobliwym życiem sławnych. Jako wielebny w Chrystusie Pan wielkiej pobożności, kapłan tegoż zgromadzenia Canonicorum Regularium, profes Jakub Oleśnicki Herbu Dembno"18. W swojej kronice, późniejszej od wydanego w 1660 roku żywota Stanisława Kazimierczyka, Stafan Ranatowicz zapisał następującą informację: „Dominus Iacobus Olesnicki, Sbignei episcopi cracoviensis germanus, de Armis Dambno, Canonicus Regularis professus Domus Nostrae de illo Christophorus Łoniewski in Vita Beati Stanislai Casimiritati" ${ }^{19}$. Wynika z niej już wprost, że informacje o Jakubie Oleśnickim pochodzą od Krzysztofa Łoniewskiego, choć nie znajdujemy ich w pierwszym wydaniu żywota Stanisława Kazimierczyka ${ }^{20}$. Jak się wydaje, ks. Ranatowicz widział rękopis tegoż żywota lub dysponował zapiskami Łoniewskiego. Krzysztof Łoniewski sugerował, że Jakub Oleśnicki był rodzonym bratem biskupa krakowskiego Zbigniewa kard. Oleśnickiego ${ }^{21}$, czyli również Jana Głowacza Oleśnickiego. Z tego już wynikają bliskie związki rodzinne między Jakubem Oleśnickim a Janem Rabsztyńskim, fundatorem klasztoru kraśnickiego, poprzez ciotkę tego drugiego, Annę Tęczyńską, będącą jednocześnie żoną brata Jakuba Oleśnickiego. Owe związki mogą okazać się jeszcze bliższe, gdy skonfrontujemy je z innymi danymi źródłowymi. Należy sięgnąć do zapisek nekrologicznych.

Człowieka o tym imieniu znajdujemy w nekrologu klasztoru Bożego Ciała na Kazimierzu w Krakowie. Pod rokiem 1504 zapisano notatkę o jego śmierci: „Obiit venerandus pater dominus Iacobus qui multis laboravit amplius officio existens koquine $[s] 1504$ "22. Jak się wydaje, pośród Jakubów wspomnianych w nekrologu, jedynie tego możemy identyfikować z Jakubem Oleśnickim herbu Dębno ${ }^{23}$. Powyższa notatka jest bowiem w zasadzie zgodna $\mathrm{z}$ tradycją o nim przekazaną przez

${ }^{18}$ Jasna pochodnia życia apostolskiego. Żywot świątobliwy b. Stanisława Kazimierczyka ... wprzód przez ks. Krzysztofa Łoniewskiego ... teraz powtóre przez ks. Stefana Ranatowicza ... wystawiona, w Krakowie 1660, k. [7v].

${ }^{19}$ Biblioteka Jagiellońska, rkps, sygn. 3742/III, Casimiriae civitatis, urbi Cracoviensi confrontatae, orgio. In eaque ecclesiarum erectiones et religiosorum fundationes, nec non series, vitae, res gestae praepositorum Conventus Canonicorum Regularium Lateranensium Sancti Augustini ad Ecclesiam Sanctissimi Corporis Christi descriptae, k. 16.

${ }^{20}$ Żywot, sprawy y cudowne Boskie wstawienie pobożnego Kapłana B. Stanisława Kazimirczyka, przy Krakowie na Kazimirzu u Bożego Ciała, Congrcgacyey Zbawicielowey: Kanoników z Literanu wedtug Reguty S. Angustyna ... Ku chwale Bożey y czci Świętych iego ... dopiro teraz Polskim ięzykiem napisany, dostateczniey y własniey niżeli byt przed tym po Łacinie wydany w roku 1609 przez X. Krzysztofa Łoniewskiego, tegoż Conwentu Kanonika. Z dozwoleniem Starszych. W Krakowie, w drukarniey Łazarzowey, Maciey Jędrzeiowczyk drukowat Roku P. 1617.

${ }^{21}$ Takie przypuszczenie wyraziła autorka biogramu Jana Oleśnickiego, ojca Jana Głowacza i Zbigniewa kard. Oleśnickiego - A. Kornecka-Trafas, Oleśnicki Jan h. Dębno, PSB, t. 23/4, z. 99, s. 764.

${ }^{22}$ Nekrolog, s. 102.

${ }^{23}$ Inne osoby o tym imieniu wymienione w nekrologu najczęściej nie są członkami klasztoru Bożego Ciała w Krakowie lub można je identyfikować po „nazwisku”. Na uwagę zasługują jeszcze tylko dwa wpisy: „Jacobus sacristianus”, ,Jacobus procurator molendinorum professus domus nostre" (Nekrolog, s. 43, 57). Są one zbyt lakoniczne, by mogły się odnosić do człowieka, który zapisał swe zasługi dla klasztoru w długotrwałej pamięci potomnych i pochodził ze znakomitego rodu, nawet jeśli w chwili jego śmierci Oleśniccy nie mieli już takiego statusu, jak w czasach kardynała Zbigniewa. 
Ranatowicza - obie wiadomości ukazują go jako człowieka pobożnego, który wiele pracy poświęcił klasztorowi. Jednak nie sposób uważać go za rodzonego brata Jana Głowacza i kardynała Oleśnickiego, jak tego chce Ranatowicz. Nasze wątpliwości budzi przede wszystkim wiek, jakiego w takim przypadku dożyłby Jakub Oleśnicki. Gdyby był on ich bratem musiałby urodzić się najpóźniej w 1413 roku, w którym umarł ojciec, Jan Oleśnicki. W chwili śmierci w 1504 roku Jakub liczyłby sobie aż 92 lata. Nie jest to oczywiście zupełnie niemożliwe, ale jednak bardzo mało prawdopodobne, biorąc pod uwagę realia średniowieczne, Jan Długosz przecież pisał o sobie mając sześćdziesiąt pięć lat, że osiągnął wiek, w którym wszyscy ludzie jego czasów przechodzą do wieczności ${ }^{24}$, Jan Głowacz żył szcześćdziesiąt lat, a kardynał sześćdziesiąt sześć. Wiek 92 lat byłby więc ewenementem. $Z$ tego powodu jesteśmy raczej skłonni twierdzić, iż Jakub nie był bratem Zbigniewa kard. Oleśnickiego i Jana Głowacza, lecz synem tego drugiego i bratankiem kardynała, a Renatowicz popełnił omyłkę, o którą nie jest przecież tak trudno ${ }^{25}$. W każdym razie nasz Jakub, zmarły w 1504 roku, był człowiekiem współczesnym Stanisławowi Kazimierczykowi, o czym zaświadcza tradycja klasztorna przekazana przez Ranatowicza, i jest najlepszym kandydatem do identyfikowania go z zaginionym krewnym Oleśnickich.

Jeżeli nasza hipoteza jest słuszna, to mamy wśród kanoników regularnych z klasztoru Bożego Ciała w Krakowie przedstawiciela rodziny Tęczyńskich - brata ciotecznego fundatora klasztoru w Kraśniku. W tej sytuacji łatwo sobie wyobrazić, kto mógłby być jednym z inspiratorów osadzenia w Kraśniku właśnie kanoników regularnych, bo niewątpliwie związki rodzinne są dość silne, by skłaniać do podążania już przetartymi szlakami.

Tak, w długim procesie dziejowym, w wyniku zrządzeń losu i świadomego namysłu przedstawicieli rodu Tęczyńskich herbu Topór, Kanonicy Regulerni Laterańscy wywodzący się bezpośrednio z czeskich Roudnic, a pośrednio z Italii, objęli swym oddziaływaniem ziemię lubelską, niosąc ze sobą ożywczy powiew odnowy życia religijnego. Przez czterysta lat wnosili ogromny wkład w rozwój kultury Kraśnika i całego regionu. Dziś możemy ich dziedzictwo podziwiać i z niego korzystać.

${ }^{24}$ „Już bowiem za łaską Bożą doszedłem do wieku wspólnego wszystkim ludziom naszych czasów. Przebiegłem bowiem w mym biegu 65 lat i ponieważ minęły godziny południowe, doszedłem do samego wieczora śmiertelnego ludzkiego bytowania i do samego kresu życia, mając wejść do królestwa światłości..." (Jana Długosza Roczniki czyli kroniki stawnego Królestwa Polskiego, księga dwunasta 1462-1480, Warszawa 2009, s. 460).

${ }^{25} \mathrm{~W}$ opracowaniu K. Łataka i S. Nalbacha, Ze studiów nad kultura umysłowa kanoników regularnych krakowskiej prepozytury Bożego Ciała w XV i XVI wieku, Kraków 2009, s. 58, 124-125, 301-302 znajdujemy próbę utożsamienia Jakuba Oleśnickiego z Jakubem Zbignei, synem rajcy kazimierskiego („,Ks. Jakub Zbignei, którego Stefan Renatowicz utożsamił z bratem kardynała, nie pochodził z rodu Oleśnickich. Był synem Zbigniewa, rajcy i burmistrza miasata Kazimierza" s. 58). Argumentacja ta jest nieprzekonująca: Jakub Zbignei zmarł najpóźniej w roku 1490, a wymieniony w Nekrologu (s. 102) Jakub, którego podejrzewamy, że był bratankiem kardynała, zmarł w 1504 roku; Jakub Zbignei więc nie jest jedyną osobą, którą można brać pod uwagę próbując wyjaśnić zagadkę Jakuba Oleśnickiego. Zresztą, we wspomnianym opracowaniu są dalej wymienieni obok siebie wśród kaznodziejów Jakub Oleśnicki i Jakub Zbignei (s. 301-302). 


\section{BIBLIOGRAFIA}

\section{Źródła}

Archiwum Kurii Archidiecezjalnej w Wilnie

sygn. f. 1 ep. 5b 8, Liber Canonicorum Regularium Conventus Vilnensis in Antocollo ad ecclesiam sancti Petri sub admodum Reverendo Domino Benedicto Samotulski praeposito conscriptus Anno Domini 1668 die 10 Decembris. Część kroniki zawierającej nekrolog nosi tytuł: Memoria defunctorum Canonicorum Regularium Congregationis Cracoviensis descripta ex libro Conventus Cracoviensis qui secundum mensem et diem notatur annus autem sequitur.

Archiwum Narodowe w Krakowie

Perg. 887

Biblioteka Jagiellońska

rkps, sygn. 3742/III, Casimiriae civitatis, urbi Cracoviensi confrontatae, orgio. In eaque ecclesiarum erectiones et religiosorum fundationes, nec non series, vitae, res gestae praepositorum Conventus Canonicorum Regularium Lateranensium Sancti Augustini ad Ecclesiam Sanctissimi Corporis Christi descriptae.

Bielak W., Dokument fundacyjny klasztoru Kanoników Regularnyvh Laterańskich w Kraśniku, „Archiwa Biblioteki i Muzea Kościelne”, 107 (2017) s. 21-32.

Jasna pochodnia życia apostolskiego. Żywot świątobliwy b. Stanisława Kazimierczyka ... wprzód przez ks. Krzysztofa Łoniewskiego ... teraz powtóre przez ks. Stefana Ranatowicza ... wystawiona, w Krakowie 1660.

\section{Opracowania}

Kurtyka J., Tęczyńscy. Studium z dziejów polskiej elity możnowładczej w średniowieczu, Kraków 1997.

Łatak K., Augustianie czy kanonicy regularni. Głos $w$ sprawie poprawnej denominacji, w: Przemijanie i trwanie. Kanonicy regularni $w$ dawnej $i$ współczesnej Polsce, Kraków [2008], s. 39-44.

Łatak K., Kongregacja krakowska Kanoników Regularnych Laterańskich na przestrzeni dziejów, Kraków 2002.

Łatak K., Ksiadz Stefan Ranatowicz CRL (1617-1694). Barokowy kronikarz i pisarz klasztorny, Kraków 2010.

Łatak K., Nalbach S., Ze studiów nad kultura umystową kanoników regularnych krakowskiej prepozytury Bożego Ciała w XV i XVI wieku, Kraków 2009.

Pęgier M., Konstrukcja Kroniki księdza Stefana Ranatowicza CRL (1617-1694) oraz wstęny zarys problematyki, „Saeculum Christianum”, 21 (2014) s. 121-130.

Wojtyska H. D., Nauka i nauczanie u kanoników regularnych, w: Dzieje teologii katolickiej, red. M. Rechowicz, t. 2, cz. 2, Lublin 1975, s. 453-507.

Zielińska E., Kultura intelektualna kanoników regularnych z klasztoru w Kraśniku 1469-1563, Lublin 2002.

słowa kluczowe: kanonicy regularni laterańscy; klasztor; Kraśnik; fundacja klasztoru kanoników regularnych 


\title{
THE CIRCUMSTANCES OF FOUNDING THE MONASTERY OF THE CANONS REGULAR IN KRAŚNIK
}

\begin{abstract}
Summary
The article presents the circumstances of founding the monastery of the Canons Regular of Lateran in Kraśnik. The author omitted the data contained in the foundation documents which had already been described in the literature on the subject. The paper focuses on the history of the Tęczyński family, whose founding activity was aimed at marking their position among the elite of medieval Poland - the times of the Tęczyński family's splendour, which followed the periods of crisis, were marked by successive foundations. In this context, the purpose of the monastery in Kraśnik was to emphasize the position of the new branch in the Topór coat of arms - Rabsztyńscy.

Attention was also paid to the Tęczyński family's connections with the Canons Regular formed at the Cracow Academy, where some members of this family studied. Finally, the author presented a mysterious and unexplained case of Jakub Oleśnicki, who, according to an old tradition, was regarded as a brother of the famous Cardinal Zbigniew - a member of the Corpus Christi Monastery in Cracow. If Jakub was indeed related to Cardinal Oleśnicki - though he was not his brother, but rather his nephew - the question of choosing the Canons Regular to run the monastery in Kraśnik would be obvious, as he would be a very close relative of the founder of the monastery, Jan Rabsztyński
\end{abstract}

Keywords: the Canons Regular of Lateran; a monastery; Kraśnik; founding the monastery of the Canons Regular 